\title{
An Analysis of the Main Causes of the Holodomor
}

\author{
Yiwei Cheng
}

The 1932-33 Ukrainian Famine has always been a very controversial topic in Ukrainian history. Scholars generally blame Stalin and his rural collectivization policy. The lack of agricultural machinery, ineffective organization and the awkward relations between the village officials and local peasants all contributed to the famine. By using both Ukrainian and Western documents, this paper is devoted to the analyzing of the main causes of the famine.

The Great Famine in Ukraine was an extremely tragic event in Ukrainian history. Although almost eighty years have passed, historians still have not reached a consensus of the major causes of the famine. Regardless of the unfavourable climatic condition, some scholars argue that the famine was a man-made genocide against the ethnic Ukrainians, while others insist on saying that the famine was not Stalin's original intention. This paper will examine the main causes of the famine with a focus on the collectivization policy in Ukraine.

Before examining its causes, it is necessary to put the famine into historical context. The Ukrainian Soviet Socialist Republic was established in 1919, and included territories east to the Dnieper River. Soon after that, in order to consolidate the Soviet rule, War Communism prevailed in all regions of the USSR, including Ukraine. Ukrainian peasants were forced to supply the Red Army with grains and other agricultural products, in order to support the army against the Whites in the Civil War. All the so-called "capitalist elements" of the economy, such as the market, private enterprises and currency, were abolished. These radical policies, together with the Civil War, left the Ukrainian economy, which was already devastated by the First World War, in ruins. Grain production fell to 25 percent of the pre-war level. The direct result was the 1921 Soviet famine, and it forced the Soviet leaders to adopt the New Economic Policy (NEP). The NEP slightly lessened the hardship of the village by replacing the solid food requisition with a tax. Then, when the domestic situation of the USSR was relatively stabilized in the late 1920s, Joseph Stalin introduced nation-wide industrialization and collectivization. Among others, Ukraine was a primary target for industrialization, and Stalin demanded 20 percent of the investment go to Ukraine. The steel plant in Zaporizhzhya, Azov and the hydroelectric power station on Dnieper River were among the twelve giant enterprises built in Ukraine. ${ }^{1}$ Collectivization, on the other hand, was to be fulfilled by the establishment of the kolhosps, or collective farms. These farms were to collectivize all the individual farms, including all the lands, tools and grain surpluses, in order to improve efficiency and offset the lack of livestock. ${ }^{2}$

\footnotetext{
${ }^{1}$ David Marples, “The Revolution from Above." Ukraine in the 20 th Century. Edmonton: University of Alberta. September 28, 2011.

2 David Marples, "Khrushchev in Power." Russia in the $20^{\text {th }}$ Century. Edmonton: University of Alberta. November 22,2010 .
} 
However, these plans that aimed at keeping up with the West seriously backfired, and the results were disastrous.

Beginning in 1929, Ukrainian collectivization was pursued relentlessly. At the same time, experienced workers were sent to these regions to accelerate the process. Peasants were given small plots to homestead, while their livestock, equipments and others were all collectivized for communal use. Also, most of the harvest was given up to the state, and only a small portion of the total yield was allocated to the peasants. The Soviet government hoped that by centralizing the distribution of the grain it could be consumed more effectively. Therefore, the farms would be able to feed the urban workers, who were to carry out industrialization, the priority of the Soviet political agenda. The peasants would therefore have to unconditionally support the working class by offering the grains they produced. As a matter of fact, grain procurement was indeed one of the main purposes for the establishment of the collective farms.

Ideally, the local authorities were to centralize grain production, extract what was needed for urban industrialization and then allocate the rest to the farmers. In reality, however, the procurement was carried out brutally, and the officials took away everything from the peasants, often to the last grain. The kolkhozniki, the collective farm members, found themselves hardly able to survive, let alone worked enthusiastically "constructing Socialism". An inhabitant of Sobolivka, Ukraine wrote to his family describing the living conditions in the countryside: "...they [the authorities] send the so-called brigades which come to a man or a farmer and conduct a search so thorough they even look through the ground with sharp metal tools... and if they find even half a pood (approximately 16.38 kilograms), they take it away on the horsewagon..."3 It was not long till the peasants realized that they worked all year round for nothing. As a result of the dire food shortage some were forced to plunder grocery stores and restaurants. Sometimes the shortage of food was so serious that the hungry people started to eat horsemeat and pig slop, and sometimes even dead bodies. The sanitary system in the kolhops was usually underdeveloped, which led to serious epidemics due to the scattered unburied bodies. ${ }^{4}$

Requisitions were not limited to the grains. Ukrainian peasants' valuables and cash were also among the things to be confiscated. According to a telegram issued by the Deputy Chairman of the OGPU, Gienrikh Yagoda, "All economic units of OGPU...should take away no less than 100,000 in hard currency itself, not counting valuables." Although this particular policy targeted the rich people, namely, the former landowners, merchants, bankers, and aristocracy settled in the countryside, it soon went out of control. Peasants were left with neither food nor money to buy food.

What was worse, the management of the Ukrainian collective farms was unsuccessful as well. Largely due to lack of agricultural machinery, the collective farms were not functioning well at all. Although the collective farms were provided with tractors and combines, most of them were

\footnotetext{
${ }^{3}$ Instytut Pamięci Narodowej, Holodomor, The Great Famine in Ukraine, 1932-1933 (Warsaw-Kiev: Toruńskie Zakłady Graficzne ZAPOLEX Sp. z o. o., 2009), 108.

${ }^{4}$ National Academy of Sciences of Ukraine and Institute of History of Ukraine, Holodomor of 1932-1933 in Ukraine: Documents and Materials (Kyiv: Kyiv Mohyla Academy Publishing House, 2008), 32.

${ }^{5}$ Instytut Pamięci Narodowej, Holodomor, The Great Famine in Ukraine, 1932-1933 (Warsaw-Kiev: Toruńskie Zakłady Graficzne ZAPOLEX Sp. z o. o., 2009), 127.
} 
unusable. There were cases in collective farms in Odessa where 27 or 29 out of 30 tractors were broken. Livestock was another problem. Before they joined the collective farms, Ukrainian peasants were so unwilling to give up their farming animals that they butchered the animals en masse. Consequently, the local farm officials sometimes sentenced them up to death penalty for killing own animals, in order to stop this livestock-slaughtering. After the forced collectivization, although the collectivized animals were distributed back to the kolkhozniki, they had no extra food to feed the animals. As a result, the animals were left either to starve or to freeze to death during winter. Another problem was that some kolhosp officials were often not trusted by the local peasants. Sometimes criminals and former kulaks were found running the farms themselves. The misuse of power such as forcing kolkhozniki to work on holidays, corruption, illegal arrests and beatings of peasants were the major reasons for the discontent among the peasants. ${ }^{6}$ They could only react against this passively, for example - by absenteeism, which led into a vicious circle.

Misinformation and the disconnection between local and central authorities were another two problems that hindered the function of the Ukrainian collective farms. During the whole collectivization process, Stalin had always been dissatisfied with grain procurement. Based on the local reports, he believed that Ukrainian black soil was supposed to yield more grain than the current level. In fact, the unrealistic local plans for grain production are explained with the fact that the collective farm officials were often people who either had very little knowledge about agriculture or wanted to make a favourable impression on the raion authorities. ${ }^{7}$ There was neither sufficient material help, such as production tools and seeds, nor sufficient instructions from the agricultural specialists given to the kolkhozniki. It was this disconnection between the local level and the Soviet Central Committee that caused the overestimation of the productive capability of the collective farms. Therefore, the quota set for the procurement kept increasing to a level absolutely impossible to attain. It was not until early 1934 that Stalin finally called a halt on the radical collectivization in Ukraine before the situation further worsened.

As a result of mismanagement and resource shortages, most of the collective farms failed to deliver the required grains. Therefore, Stalin began to suspect that there might be people hoarding grains. The Soviet laws strictly forbade all the depositing and trading of agricultural products in the countryside, such as flour, seeds and bread, until the set quota was fulfilled. The official transportation of grains was under supervision of the local authorities. Any unauthorized personnel holding more than one pood of grain was considered an illegal grain trader or speculator. Thus, the Dekulakization movement was in response to kulaks and speculators who were believed to sabotage the Soviet industrialization by hiding grains. The goal was to carry out class struggle in the countryside by destroying these class enemies. However, the ration distributed to the kolkhozniki, 10 poods a month (about 163.8 kilograms), was far from enough. Sometimes the desperate peasants secretly traded their valuables for some food from the underground grain traders. When they were discovered, these traders were made the scapegoats

\footnotetext{
${ }^{6}$ Instytut Pamięci Narodowej, Holodomor, The Great Famine in Ukraine, 1932-1933 (Warsaw-Kiev: Toruńskie Zakłady Graficzne ZAPOLEX Sp. z o. o., 2009), 155.

${ }^{7}$ Instytut Pamięci Narodowej, Holodomor, The Great Famine in Ukraine, 1932-1933 (Warsaw-Kiev: Toruńskie Zakłady Graficzne ZAPOLEX Sp. z o. o., 2009), 186.
} 
for failure to deliver enough grains for export and for supporting urban industrialization. According to the Soviet government, these people illegally deposited and elevated the price of the agricultural products. They were the class enemies that should be immediately arrested and deported to the labour camps. ${ }^{8}$ Apart from the executed and the deported kulaks, those who were allowed to stay were taken all the valuables, and their houses were plundered by the locals. Again, due to misjudgement and other reasons, the Dekulakization went far beyond its original goal since there was no clear-cut definition for the kulaks. In Ukraine alone, over one million peasants lost their farms, and about 850,000 were deported. ${ }^{9}$

To make situations even worse, the collective farms forbade the hungry Ukrainian peasants to leave the village to seek food elsewhere. By resurrecting the internal passport system in 1932, the Soviet government could keep track of all the urban residents and workers in order to find the hiding kulaks among them. Kolkhozniki and other individual peasants were not given passports and could not move from their place of permanent residency without permission. However, a secret tendency for some peasants was to plan to abandon and the escape village. In some places, a "systematic escape from the countryside to the cities" began in early $1932 .{ }^{10}$ Some kulaks and the better-off peasants, out of fear of the local confiscation, closed down their farms and tried to move to the city. In response, the Soviet government demanded those who attempted to run away from collectivization be deported or sent to the labour camps once caught.

Despite the prohibition on fleeing the village, cross-border escape still happened very often. According the record of one Polish-Soviet border register on April 19, 1932, four escapees were caught crossing the border into Poland. They revealed that their home village was stricken by a terrible hunger, particularly among the kolkhozniki. They had to run away because their monthly ration was below the minimal amount needed. ${ }^{11}$ This kind of report was not rare during the period of 1932-1933. Some managed to escape and settle down in other European countries or even North America, while many failed and were transferred back. During the height of the famine in 1933, the Ukrainian borders were closed to prevent further escape. Approximately 190,000 Ukrainian peasants were caught fleeing the country and were sent back. ${ }^{12}$ Starvation was usually what waited for them, if not deportation and execution. Many others were simply shot by the Soviet border guards.

However, it is not fair to say that the famine was completely a result of the unsuccessful collectivization. Natural causes were also partly responsible, but were definitely not the sole reason. For lack of advanced agricultural technology, grain yield in Ukraine was mostly still dependant on weather during the early twentieth century. Droughts occurred on a regular basis,

\footnotetext{
${ }^{8}$ Instytut Pamięci Narodowej, Holodomor, The Great Famine in Ukraine, 1932-1933 (Warsaw-Kiev: Toruńskie Zakłady Graficzne ZAPOLEX Sp. z o. o., 2009), 273.

${ }^{9}$ James E. Mace, Communism and the Dilemmas of National Liberation: National Communism in Soviet Ukraine, 1918-1933 (Cambridge: Harvard University Press, 1983), 283.

${ }^{10}$ Instytut Pamięci Narodowej, Holodomor, The Great Famine in Ukraine, 1932-1933 (Warsaw-Kiev: Toruńskie Zakłady Graficzne ZAPOLEX Sp. z o. o., 2009), 113.

11 Ibid.

${ }^{12}$ Instytut Pamięci Narodowej, Holodomor, The Great Famine in Ukraine, 1932-1933 (Warsaw-Kiev: Toruńskie Zakłady Graficzne ZAPOLEX Sp. z o. o., 2009).
} 
and often led to famines. The 1931 drought, together with an abnormally cold spring and a hot July, devastated the harvest of the year. It also caused a shortage of seed, which, in turn, affected the spring sowing of $1932 .{ }^{13}$ These unfavourable climatic conditions continued to 1932 and 1933. However, under such difficult circumstances, the Soviet government refused to reduce the requisition quota imposed on all the kolhosps. Stalin demanded that rapid industrialization, being the top priority, not be stopped. Therefore, the fixed amount of grains provided by the countryside must be delivered. Two historians R.W. Davies and Stephen Wheatcroft attempted to clarify the mentality of the Politburo, "...they emphasized that Bolshevik organization and determination could overcome the difficulties."14 Therefore, it is clear that although the drought did play a role in the famine, it is only a minor cause of the famine.

Most of the confiscated grain, apart from what supported the urban workers and the army, was exported in order to acquire hard currency. Despite the shortage of food, oils and seeds were exported as well, especially after the 1931 drought. Traditionally, Ukraine was a major producer of grain, sugar and sunflower oil because of its vast arable land, and the export of agricultural products used to take a fair share of the national income. However, Ukrainian economy was completely paralyzed by the First World War and the subsequent Civil War. After being absorbed by the Soviet Union, although the country's industry developed rapidly, its agriculture never fully recovered from the war devastation. Continuous grain export obviously did not help to relieve the shattered Ukrainian agriculture. Having been aware of the situation, the Soviet government still attempted to justify its export policy. According to a report of an employee of the Italian Consulate, the best quality flour was being sent abroad, while the Ukrainians were starving or only given bread of poor quality. The purpose was to make the foreigners think that if the good flour was exported, even better flour must have been kept. ${ }^{15}$ This demonstrated Stalin's resolution to compete with the West, even at the expense of the Ukrainians and others who perished in the famine.

As is argued above, the disappearance of labour forces, no matter whether they were convicted as kulaks, speculators or other criminals, caused hardship for those who stayed behind. Some scholars of this area argue that the Ukrainian Famine was a man-made genocide against the ethnic Ukrainians, who were stereotyped as nationalists and counterrevolutionaries. As a result of the sharp population decrease, lands were left fellow, livestock starved and the machinery rusted. The impoverished collective farms, combined with execution and deportation of peasants, aroused bitter reactions among the kolkhozniki. Many Western observers and diplomats of the time believed that there would be nation-wide upheaval in Ukraine against the Soviet rule. In fact, in Slobidka, Peresyp and bazaars in Odessa, regional unrests broke out often as a result of difficulties with supplies. Most of the cases, the hungry people just plundered the local grocery stores and restaurants and left. However, those unrests antagonized the Soviet government and the NKVD. They were convinced there were counterrevolutionary organizations comprising of

13 R. W. Davies and Stephen G. Wheatcroft, The Years of Hunger: Soviet Agriculture, 1931-1933 (Basingstoke, Hampshire: Palgrave Macmillan, 2004), 112.

${ }^{14}$ Ibid., 74.

${ }^{15}$ Instytut Pamięci Narodowej, Holodomor, The Great Famine in Ukraine, 1932-1933 (Warsaw-Kiev: Toruńskie Zakłady Graficzne ZAPOLEX Sp. z o. o., 2009), 55. 
agricultural experts that were mainly concerned with undermining the economic power of the Soviet Union in the countryside. For example, the All-Ukrainian Agronomic Society (VAO) in Podolia was believed to be an organization of the former landowners and intelligentsia, and its ultimate goal was the overthrow of Soviet rule and establishment of a bourgeois republic. Most of the members became the victims of the purge. ${ }^{16}$ The elimination of the VAO was not an individual event. Organizations and societies of that kind were often considered to have a connection with the "nationalist bourgeoisie", or to be "Petlyura sympathizers". The western part of Ukraine was still under Polish influence in the early 1930s, and although Semon Petlyura was long gone, his government-in-exile was still active in Poland. The Soviet government felt threatened by the potential danger brought by the Ukrainian nationalists.

The renowned historian Robert Conquest suggests at the beginning of his book, The Harvest of Sorrow, that "the 'revolution from above', in which [Stalin] and his associates crushed two elements seen as irremediably hostile to the regime: the peasantry of the USSR as a whole, and the Ukrainian nation."17 The Ukrainian peasants' failure to deliver enough grain was explicitly blamed on nationalism, therefore, the national problem was in essence a peasant problem. Expectably, a famine would be the best solution to this problem, because by destroying the Ukrainian peasantry, all the nationalists would therefore be eliminated. Thus, there was the word Holodomor, or 'killing by hunger.'

To say that the main reason for the famine was Stalin's plan to remove the Ukrainian nationalists is reasonable, but there are several counter-arguments. Undoubtedly, the village elites, such as the kulaks and the intelligentsia, might have had some connection with the small groups of nationalists who were presumably hiding in the countryside. These nationalists, along with their collaborators, namely the kulaks and others, were the targeted anti-Communists. However, the majority of the poor peasants, a lot of whom were still illiterate, were unlikely to have much to do with the nationalists. Moreover, although Ukraine endured a huge loss during the famine, it was not the only one. Other regions including Northern Caucasus, Volga Region and Kazakhstan were also seriously affected by the famine and millions of lives were lost. This may indicate that the Ukrainians were unlikely the sole target of the famine.

In conclusion, the Ukrainian famine was mainly a result of the unsuccessful collectivization policy. Primarily, the collective farms themselves failed to provide the kolkhozniki with sufficient agricultural machinery and livestock. This was worsened by ineffective management, often by people with little agricultural knowledge. Based on the over-ambitious reports, the Central Committee set unrealistic quotas that could never be reached. Furthermore, the grain procurement and village Dekulakization got out of control, leaving peasants barely anything to feed themselves. Millions were deported or executed. The desperate peasants who left behind were forbidden to leave the village, which literally sentenced them to death. In addition, the severe drought in the early 1930s pushed the famine to its apex. Stalin isthe person who should be responsible for the tragedy. However, this is not to say that he, along with the Soviet Central

\footnotetext{
${ }^{16}$ Instytut Pamięci Narodowej, Holodomor, The Great Famine in Ukraine, 1932-1933 (Warsaw-Kiev: Toruńskie Zakłady Graficzne ZAPOLEX Sp. z o. o., 2009), 83.

${ }^{17}$ Robert Conquest, The Harvest of Sorrow: Soviet Collectivization and the Terror-Famine (London: Hutchinson, 1986), 3.
} 
Committee, deliberately intended to eliminate the ethnic Ukrainians. It was a bitter consequence of the rural collectivization under Stalin's rule, rather than a designated ethnic genocide. 


\section{Bibliography}

Conquest, Robert. The Harvest of Sorrow: Soviet Collectivization and the Terror-Famine. London: Hutchinson, 1986.

Davies, R. W. and Stephen G. Wheatcroft. The Years of Hunger: Soviet Agriculture, 1931-1933. Basingstoke, Hampshire: Palgrave Macmillan, 2004.

Instytut Pamięci Narodowej. Holodomor, The Great Famine in Ukraine, 1932-1933. Warsaw-Kiev: Toruńskie Zakłady Graficzne ZAPOLEX Sp. z o. o., 2009.

Mace, James E. Communism and the Dilemmas of National Liberation: National Communism in Soviet Ukraine, 1918-1933. Cambridge: Harvard University Press, 1983.

Magocsi, Paul Robert. Ukraine, An Illustrated History. Toronto: University of Toronto Press, 2007.

Marples, David. "History 317: Ukraine in the 20th Century" and "History 322: Russia in the 20th Century” Course Notes. Edmonton: University of Alberta. 2010-2011 and 2011-2012.

National Academy of Sciences of Ukraine and Institute of History of Ukraine. Holodomor of 1932-1933 in Ukraine: Documents and Materials. Kyiv: Kyiv Mohyla Academy Publishing House, 2008. 